\title{
Bravman Leads 1994 Executive Committee
}

\author{
Now in its 21st year, with a membership \\ of more than 11,600 , the \\ Materials Research Society welcomes a new slate \\ of officers to lead its efforts in 1994.
}

John C. Bravman, associate professor and associate chairman of the Department of Materials Science and Engineering at Stanford University, is the new 1994 MRS president, a position he assumes automatically from his elected office of first vice president in 1993 . He succeeds Tom Picraux, manager of the Semiconductor Physics Research Department at Sandia National Laboratories, who now serves the Society as immediate past president.

Joining Bravman and Picraux as newly elected members of the Executive Committee are Julia M. Phillips (AT\&T Bell Laboratories), first vice president and president-elect for 1995; Carl V. Thompson (Massachusetts Institute of Technology), second vice president; and Carl C. Koch (North Carolina State University), secretary, all elected in the 1993 ballot. A. Kay Hays (Sandia National Laboratories) will continue to serve as treasurer.

In addition, Howard K. Birnbaum (University of Illinois), Kevin S. Jones (University of Florida), and Merrilea J. Mayo (Pennsylvania State University) were elected to three-year terms on the MRS Council. They join councillors Bill
R. Appleton (Oak Ridge National Laboratory), Aaron N. Bloch (State University of New York-Buffalo), R.P.H. Chang (Northwestern University), Russell R. Chianelli (Exxon Research and Engineering), Clifton W. Draper (AT\&T-ERC), Merton C. Flemings (Massachusetts Institute of Technology), J. Murray Gibson (University of IllinoisUrbana), Robert Hull (AT\&T Bell Laboratories), Carol M. Jantzen (Westinghouse Savannah River Company), June D. Passaretti (Specialty Minerals, Inc.), Paul S. Peercy (Sandia National Laboratories), and Richard W. Siegel (Argonne National Laboratory).

\section{John C. Bravman \\ President}

John Bravman is an associate professor and associate chairman in the Department of Materials Science and Engineering at Stanford University. He is also senior associate dean for student affairs in the School of Engineering. His research interests focus on the processing and analysis of thin-film materials and structures. Currently, he directs doctoral students in silicon and gallium arsenide process technology, the mechanical prop- erties of thin films, high-temperature superconductivity, and transmission electron microscopy.

After receiving his $\mathrm{BS}, \mathrm{MS}$, and $\mathrm{PhD}$ degrees in materials science from Stanford, Bravman worked at the Fairchild Semiconductor Research and Development Laboratories in Palo Alto, California. He also served as a consultant with several Silicon Valley firms, including Lockheed, National Semiconductor, Advanced Micro Devices, and IBM. He has co-authored 90 research publications.

Active in many phases of teaching, research, and student advising, Bravman has received numerous awards from Stanford, including the Walter J. Gores Award, the university's highest excellence-in-teaching award. Among other honors Bravman has received are ASM International's Bradley Stoughton Award for Young Teachers in 1991, and the Excellence in Teaching Award from the Society of Women Engineers in 1992.

Bravman was MRS second vice president for 1992 and an MRS councillor. He co-chaired the 1990 MRS Spring Meeting, has organized six symposia, and has served on several committees. He is also a member of the MRS Bulletin's Technical Editorial Board.

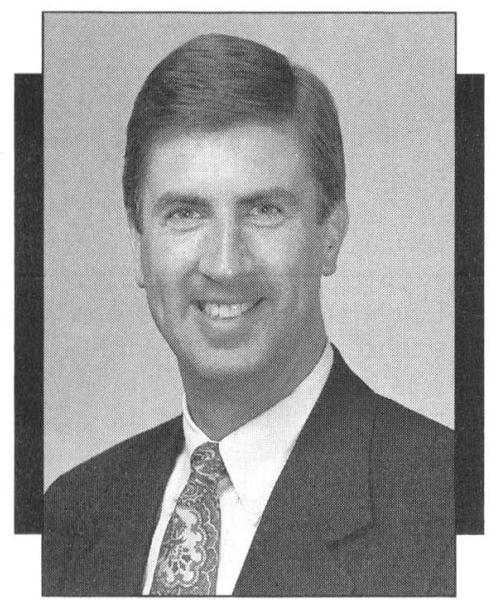

John C. Bravman

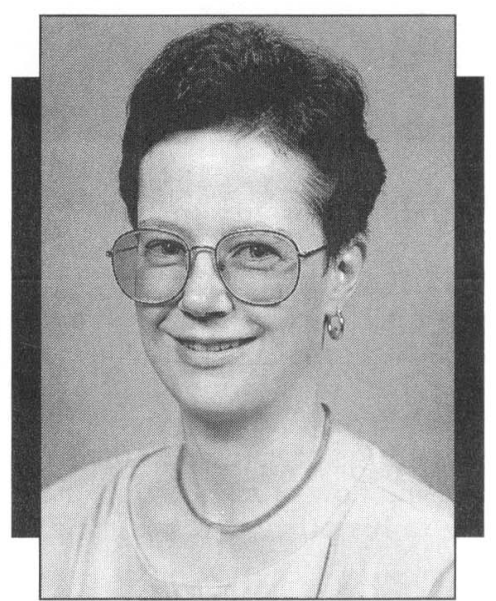

Julia M. Phillips

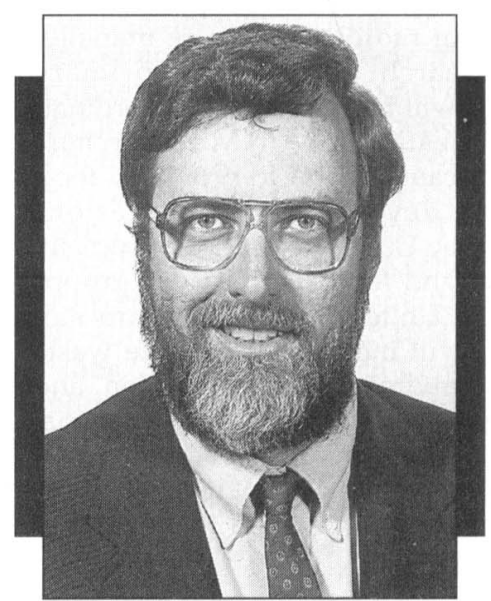

Carl V. Thompson 
Bravman looks forward to leading and serving the Materials Research Society at a time of rapid growth and its attendant demands. "Over the past decade," says Bravman, "MRS has advanced into the front ranks as an international scientific organization. For our membership, the implications of that growth are significant and diverse, demanding thoughtful leadership on the part of each person involved in managing Society affairs." One of the Society's greatest challenges, he says, will be maintaining a balance between MRS's mandate to be "faithful to our heritage as an interdisciplinary society at the forefront of science and technology" and the need to be "open to change and to new opportunities."

Among areas demanding immediate attention, notes Bravman, is the burgeoning size of the Fall and Spring annual meetings. Other opportunities for change, says Bravman, include using technologies such as electronic publishing and electronic bulletin boards. (See Letter from the President, p. 3.)

\section{Julia M. Phillips \\ First Vice President}

Julia Phillips is supervisor of the Thin Film Research Group at AT\&T Bell Laboratories and manager of the High $\mathrm{T}_{c}$ Materials and Technology Program of the Consortium for Superconducting Electronics. Her research centers on heteroepitaxy, with a concentration in thin film growth of diverse materials, including high-temperature superconductors and other oxides.

Phillips' other interests include epitaxial insulators and metals on semiconductors, and structural and electrical characterization of these heterostructures; ion beam analysis; and application of rapid thermal processing techniques to heteroepitaxy.

Phillips received her BS degree in physics from the College of William and Mary and her PhD degree in applied physics from Yale University. She is a member of the American Physical Society and Sigma Xi.

Phillips has served as MRS secretary (1987-89), as second vice president (1993), and as a councillor (1991-93). She has been a symposium organizer, has chaired the 1991 Fall Meeting, and has chaired several MRS committees, including the Program, Publicity and Public Relations, and Corporate Participation committees. Phillips is a principal editor of Journal of Materials Research and a member of the editorial board of Applied Physics Letters/Journal of Applied Physics.

\section{Carl V. Thompson \\ Second Vice President}

Carl V. Thompson is a professor of electronic materials in the Department of Materials Science and Engineering at the Massachusetts Institute of Technology (MIT). A materials science and engineering graduate of MIT, he received his SM and $\mathrm{PhD}$ degrees in applied physics from Harvard University, then returned to MIT as an IBM postdoctoral associate in the Research Laboratory of Electronics. He joined the Materials Science and Engineering faculty in 1983.

Thompson spent the 1990-91 academic year at Cambridge University as a U.K. Science and Engineering Research Council visiting fellow. He has worked briefly in the research departments of a number of major U.S. companies and has served as a consultant for such firms as IBM and Digital Equipment Corporation.
Thompson's research interests focus on the relationships among processing, structure, properties, and performance of thin films used in electronic devices and circuits and magnetic devices and systems. He and his students have studied and modeled grain growth and recrystallization in semiconductor and metallic films, and also the effect of microstructure on electromigration in interconnects, contacts, and vias.

Since joining MRS, Thompson has coorganized two MRS symposia on polycrystalline $\mathrm{Si}$, an MRS symposium on thin-film structure evolution, and a symposium on materials reliability in microelectronics. He also was co-guest editor of the December 1993 MRS Bulletin on reliability in microelectronics. He cochaired the 1990 MRS Spring Meeting and was a co-organizer of the Mechanisms of Thin Film Evolution Symposium at the 1993 MRS Fall Meeting. Thompson has served on the MRS Continuing Education Committee, the Program Committee, and the Academic Affairs Committee. He chaired the Audit Committee for two years, and will also chair the Program Development Subcommittee. In 1993 he completed a threeyear term on the MRS Council.

\section{Carl C. Koch \\ Secretary}

Carl C. Koch is a professor of materials science and engineering and an associate department head at North Carolina State University. His research interests center around nonequilibrium processing, intermetallic compounds, and high $\mathrm{T}_{\mathrm{c}}$ superconducting oxides. His current projects include studies of nanocrystalline materials; the phase stability, mechanical, and oxidation behavior of

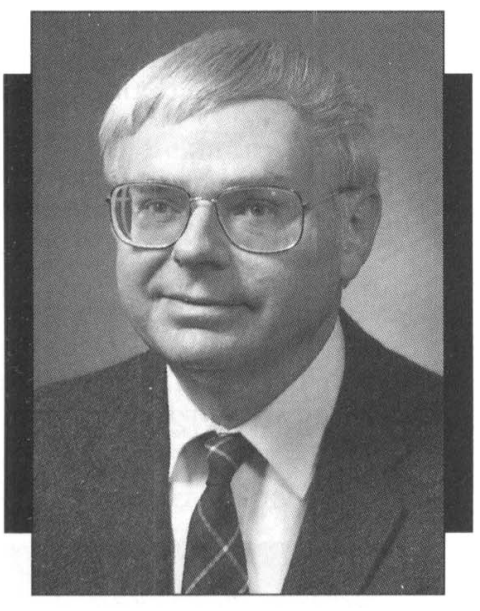

Carl C. Koch

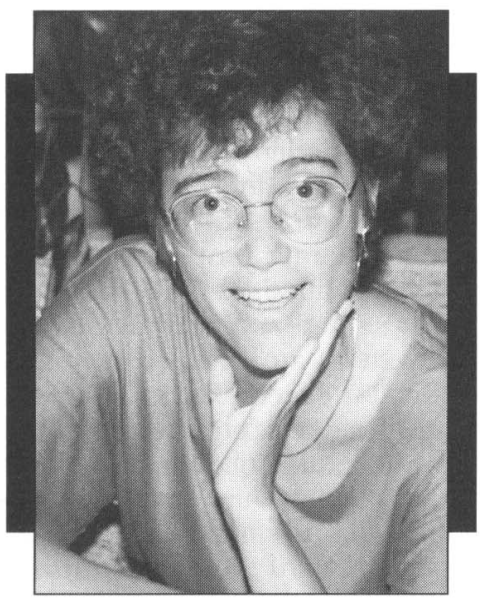

A. Kay Hays

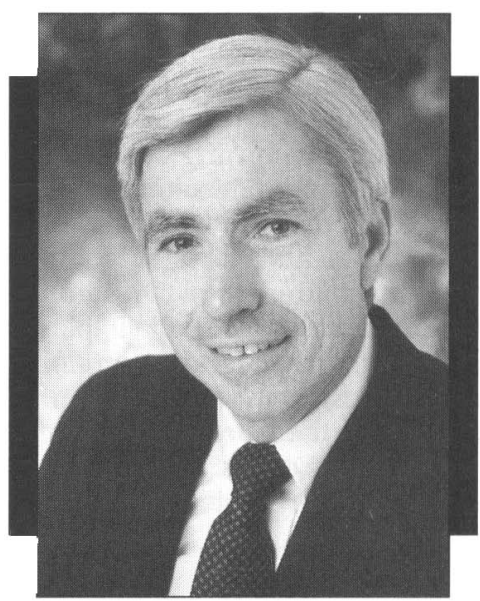

Tom Picraux 
selected intermetallic compounds; and the factors that influence the superconducting critical current density in the high $T_{c}$ oxide superconductors.

Koch received his $\mathrm{PhD}$ degree in metallurgy from Case Institute of Technology, then served as a National Science Foundation Fellow at Birmingham University, England. In 1965 he joined Oak Ridge National Laboratory, later becoming a group leader in superconducting materials. He joined the North Carolina State University faculty in 1983.

A fellow of the American Physical Society, ASM International, and the American Association for the Advancement of Science, Koch has received the Department of Energy's Metallurgy and Ceramics Award, an IR-100 Award, an NSF Research Award for Special Creativity, and the ALCOA Distinguished Research Award. He is the coholder of three patents and has co-edited four books and authored or co-authored more than 130 papers.

His contributions to MRS include coorganizing three MRS symposia on hightemperature ordered intermetallic alloys. He was one of three chairs for the 1992 MRS Fall Meeting and a former president of the MRS North Carolina Section. Koch currently serves on the MRS Program, Academic Affairs, Membership, and Awards committees.

\section{A. Kay Hays Treasurer}

A. Kay Hays is manager of Industrial Program Development in the Engineered Materials and Processes Directorate at Sandia National Laboratories. She received her MS degree in chemistry from the University of CaliforniaBerkeley and her PhD degree in physical chemistry from the University of California-Los Angeles.

Starting as a staff researcher at Sandia, Hays worked in laser physics, developing high-power, ultraviolet lasers for inertial confinement fusion. Changing from plasma physics to plasma chemistry, she began developing radio-frequency plasma deposition techniques for different applications.

Later, Hays became supervisor of Sandia's Coating Research Division, where work is done in CVD, PVD, plasma deposition, thermal spray, and electrochemical deposition efforts. She currently coordinates the laboratory's materials response to DOE's Technology Commercialization Initiative (TCI). She serves, in part, as Sandia's representative on the Materials Technical Area Coordinating Team, which is responsible for developing a strategic plan for the DOE laboratories' materials interaction with U.S. industry and for reviewing programs funded by TCI.

Active in both the American Vacuum Society and MRS, Hays served on the executive committee of the Vacuum Metallurgy Division of AVS. She was coorganizer of the 1988 MRS Spring symposium on process diagnostics and was a meeting chair for the 1991 MRS Spring Meeting.

\section{Tom Picraux \\ Immediate Past President}

Tom Picraux is manager of the Semiconductor Physics Research Department at Sandia National Laboratories. He joined Sandia in 1969 as a member of the technical staff in ion-solid interactions research. Since 1972 he has managed various solid-state science activities at Sandia, including ion beam science, surface and interface science, defect physics, microsensor research, and semiconductor physics. Picraux is recognized for his development of ion channeling and its application to materials research. In 1990 he received the Department of Energy's E.O. Lawrence Award for materials research, based on this work.

An electrical engineering graduate of the University of Missouri, Picraux attended Cambridge University as a Fulbright Fellow in physics and later earned a PhD degree in engineering science and physics from the California Institute of Technology. He has published more than 200 papers and has served on a number of studies for the National Research Council.

Picraux was a founding editor and, until 1992, co-editor of the Journal of Nuclear Instruments and Methods, Section $B$, and currently serves on the editorial boards of several journals. He has been a member of numerous international conference committees and advisory boards, and a visiting scientist at educational and research organizations.

Picraux joined MRS in the 1970s, chaired several symposia during the 1980s, and chaired the 1987 Fall Meeting. He later served as Program Committee chair and was a councillor from 1988 to 1990. In 1991, Picraux was elected MRS second vice president and became first vice president the following year.

MIRS

\section{Reach the MS\&E Market with Mailing Lists from the Materials Research Society}

The Materials Research Society maintains an extensive database (over 120,000 names) of scientists and research managers who are active in forefront areas of materials research and engineering. Categories and subcategories are grouped several ways to help you target your mailing appropriately.

The lists are grouped in 4 main categories:

- Materials by application

- Materials by properties

- Materials characterization

- Materials processing

... and in 40 subcategories under those. You can select lists of individuals in any combination on cheshire or pressure-sensitive labels.

MRS reserves the right to deny requests for labels which are intended for mailings in conflict with its programs, principles, or other interests.

For rental information, and a complete breakdown of available categories and counts, please contact:

Mary E. Kaufold

Materials Research Society 9800 McKnight Road Pittsburgh, PA 15237

Phone (412) 367-3036 FAX (412) 367-4373 